\title{
КОМУНІКАТИВНА ТОЛЕРАНТНІСТЬ ЯК ПСИХОЛОГІЧНИЙ ЧИННИК СПРАВЕДЛИВОСТІ У ПЕДАГОГІЧНІЙ ВЗАЕМОДІЇ
}

\author{
Лілія Клочек \\ доктор психологічних наук, доцент, \\ доцент кафедри філософії, політології та психології \\ Центральноукраїнський державний педагогічний університет \\ імені Володимира Винниченка \\ 25000, Україна, м. Кропивницький, вул. Шевченка, 1 \\ klochek155@i.ua, http://orcid.org/0000-0002-6450-3374 \\ Ігор Уличний \\ кандидат педагогічних наук, доцент, \\ доцент кафедри педагогіки спеціальної та соціальної освіти \\ Центральноукраїнський державний педагогічний університет \\ імені Володимира Винниченка \\ 25000, Україна, м. Кропивницький, вул. Шевченка, 1 \\ ulychil@gmail.com
}

\begin{abstract}
Анотація
У статті презентуються результати теоретичного та емпіричного вивчення комунікативної толерантності вчителів, яка виявляється у взаєминах зі школярами. Вказується на те, що досягнення справедливості у цьому процесі зумовлюється виявом учителем толерантного ставлення до них. Комунікативна толерантність виступає якістю (цінністю) педагога, що в діалогічній взаємодії з другою стороною освітнього процесу виявляється у прийнятті особистості кожного учня, розумінні мотивації його поведінки, повазі до ціннісно-смислових позицій та установок. Зауважується, що рівень розвитку комунікативної толерантності вчителя свідчить про його готовність будувати стосунки зі школярами на засадах гуманності, неупередженості та справедливості. Визначається методологічна основа дослідження, а саме ціннісно-діалогічний підхід, згідно основних положень якого справедливість у взаємодії учасників освітнього процесу досягається завдяки ціннісному, толерантному ставленню вчителя до учнів через налагодження з ними конструктивного діалогу. Наводяться результати емпіричного дослідження. Виявлено досить розвинену загальну комунікативну толерантність у сучасних учителів. Встановлено, що у вчителів-початківців і у педагогів, які мають набутий професійний досвід, переважають середній i високий рівні загальної комунікативної толерантності. Разом з тим, констатовано, що в різноманітних ситуаціях указана особливість має різний ступінь вияву. У вчителів з незначним педагогічним стажем, порівняно зі старшими колегами, переважає середній рівень здатності приймати індивідуальність учнів, оцінювати їх на основні власного «Я», приховування негативного ставлення до них. Зауважується, що у вчителів, які мають значний педагогічний досвід, більшою мірою розвинена схильність приймати учнів з їх перевагами та недоліками, не вдаватися до негативних поведінкових тенденцій та виявляти адаптивність у взаєминах. Узагальнюється, що вказані особливості вчителя та відсутність категоричності в оцінці учнів зумовлюють досягнення справедливості у педагогічній взаємодії.
\end{abstract}


Ключові слова: справедливість, комунікативна толерантність, ціннісне ставлення, справедливі дії, неупередженість.

\section{Ветуп}

На сучасному етапі розвитку вітчизняної освіти актуалізуються проблеми гуманізації педагогічних взаємодій, де особлива увага приділяється вивченню справедливості у взаєминах учителів і учнів, дотримання ними норм поваги один до одного, визнання гідності особистості кожного учасника освітнього процесу. Вказане детермінується рядом зовнішніх і внутрішніх чинників. Серед останніх виокремлюється комунікативна толерантність - особистісне утворення вчителя, що зумовлює його ціннісне, справедливе ставлення до учнів як об'єктів педагогічного впливу та суб'єктів діалогічної комунікативної взаємодії.

Проблема толерантності є предметом вивчення філософії освіти - області філософського знання про цінності освітньої роботи, діяльності педагога як ключової фігури освітнього процесу. В своїх філософських роздумах Х. Туріньян провідною ідеєю теорії соціального виховання зростаючої особистості визначав культивацію цінностей мирного, а відтак плідного співіснування людей у соціокультурному просторі, розуміння іншого, поваги до його неповторності та індивідуальних виявів (Tourinan, 2008).

В. Кременю належить думка про те, що через освіту, зокрема виховання, у навчальновиховному процесі стверджується толерантність чи то як діалог культур, чи як сповідування на рівні свідомості принципу поваги до іншого, у всьому розмаїтті його проявів (Кремень, 2011).

Н. Хамітов підкреслював, що конструктивно взаємодіяти, ефективно комунікувати 3 іншими здатна тільки толерантна людина, оскільки вона поважає їх права і свободи. Досліднику належить думка, що в основі ідеї толерантності лежить повага до людини - як такої, що здатна мислити, висловлюватися та діяти (Хамітов, 2009). Проектуючи ці погляди на сферу освіти, Р. Кузьменко визначала толерантність в освітньому процесі як повагу та розуміння, доброзичливе ставлення до здобувачів, «рівність у висловлюванні думок, ідей та поглядів». Справжні толерантні взаємини між учасниками освітнього процесу вибудовуються в метаграничному бутті між учителем і учнями, коли той не тільки виконує професійну функцію доносити знання до останніх, але виходить на такий рівень взаємодії, де виникає взаємна повага, налагоджуються шанобливі стосунки, утверджується справедливість (Кузьменко, 2020).

3 точки зору психології, толерантність визначається як «індивідуальна якість, характерологічна властивість особистості, найчастіше притаманна тим людям, за результатами поведінки яких можна говорити, що вони є високоморальними, гуманними, такими, що можуть зрозуміти іншу людину, готові підтримувати на належному рівні власну якісну адаптацію у відношенні до усіх різновидів соціального життя» (Карпюк, 2019).

Д. Бродський толерантністю називав особливість особистості шанобливо ставитися до іншого, навіть якщо його дії є такими, що не приймаються соціумом. Дослідник пов'язував толерантне ставлення із соціальною відповідальністю (Бродский, 2002). Остання спонукає особистість об’єктивно сприймати результати діяльності чи поведінки інших людей i виносити справедливі рішення.

В. Ліпатов зауважував, що в освітньому процесі вчителі мають орієнтуватися на тип толерантності, згідно якого, в контексті ведення зі школярами критичного діалогу, відбувається прийняття їх особистості, виявляється повага до цінностей і смислів школярів, 
виникає розуміння мотивації вчинків та причин досягнення певних результатів у діяльності (Ліпатов, 2008).

Можемо стверджувати, що в контексті вивчення толерантних виявів особистості у сфері педагогічних взаємодій, актуалізується проблема розвитку комунікативної толерантності у вчителя як якості (цінності), що детермінує досягнення справедливості у взаєминах учасників освітнього процесу. 3 точки зору Ю. Карпюк, комунікативна толерантність є особистісною якістю, наявність якої свідчить про готовність і спроможність позитивно взаємодіяти з іншими людьми, виявляючи до них емпатію та повагу, що грунтується на певному рівні розвиту інтелектуальної гнучкості та здатності до самоконтролю (Карпюк, 2019).

А. Скок у своєму тлумаченні комунікативної толерантності акцент робила на здатності людини взаємодіяти з іншими. Виявляючи вказану особливість, вона пізнає як власну особистість, спроможну до гуманної поведінки та рівноправного спілкування, так і іншу людину (Скок, 2011).

Ми вважаємо, що комунікативна толерантність учителя зводиться до поваги щодо прав учнів, співвідноситься з утвердженням дводомінантності позицій обох суб'єктів освітнього процесу, тобто їх рівноправності у висловленні своїх ставлень відносно різних аспектів педагогічної взаємодії. Вирішуючи складні ситуації у взаєминах з учнями, вчитель апелює до норм справедливості, виявляє свою комунікативну толерантність через ведення педагогічного діалогу (Клочек, 2019).

Мета статті полягає у вивченні особливостей комунікативної толерантності вчителів закладів загальної середньої освіти, впливу цієї якості на справедливість у педагогічній взаємодії. Реалізація поставленої мети передбачає вирішення наступних завдань: 1) обгрунтувати психодіагностичний інструментарій для емпіричного вивчення досліджуваної проблеми; 2) виявити особливості розвитку у вчителів комунікативної толерантності, яка зумовлює їх справедливе ставлення до учнів.

\section{Методи дослідження}

Вивчення комунікативної толерантності вчителів як психологічного чинника справедливості у педагогічній взаємодії ми здійснювали на засадах ціннісно-діалогічного підходу, згідно основних положень якого справедливість у взаєминах учасників освітнього процесу досягається завдяки ціннісному, неупередженому, толерантному ставленню вчителя до учнів, утвердженню психологічної рівності між ними через налагодження діалогу (Клочек, 2019).

Емпіричне дослідження відбувалося 3 використанням методики «Діагностика комунікативної толерантності» (авт. В.В. Бойко) (Фетіскін, 2005). Мета методики полягала в тому, щоб виявити рівень комунікативної інтолерантності досліджуваних, що при низьких показниках цієї якості свідчило про протилежну рису - толерантність. Респондентам пропонувався опитувальник, де потрібно було оцінити себе в дев'яти ситуаціях соціальної (в контексті нашого дослідження - педагогічної) взаємодії: наскільки вони здатні приймати індивідуальність учнів; чи властива тенденція не оцінювати їх на основні власного «Я»; чи має місце (або ж відсутня) категоричність в оцінці школярів; чи схильні приховувати негативне ставлення до них; наскільки здатні не переробляти особистість учнів; чи схильні не пристосовувати до себе їх як партнерів по спілкуванню; чи властиві досліджуваним поведінкові тенденції недоброзичливості, вияву образи, злопам’ятності, бажання помститися 
іншому за його безтактність; чи має місце терпимість до дискомфортних негативних станів школярів; чи актуалізуються адаптаційні здібності у взаємодії з ними.

Згідно змісту методики, до кожної ситуації наводилося по п'ять суджень, кожне з яких потрібно було оцінити наступним чином: 0 балів - якщо з точки зору досліджуваних судження $€$ зовсім неправильним, 1 бал - дещо правильним, 2 бали - правильним значною мірою, 3 бали - найбільш правильним.

При обробці результатів підраховувалася сума отриманих балів за кожною ситуацією та визначалася загальна сума балів за всіма ситуаціями.

За кожною ситуацією мінімально респонденти могли набрати 0 балів і максимально 15 балів. Чим бал вищий, тим нижчим є рівень толерантності в певному аспекті. I навпаки чим бал нижчий, тим більшу толерантність виявляють досліджувані у різних ситуаціях педагогічної взаємодії. Отримані результати дозволили виявити, як ті чи інші прояви комунікативної толерантності вчителів у практиці взаємодії з учнями впливають на винесення справедливих педагогічних рішень та їх реалізацію.

Загальна сума набраних балів максимально могла сягати 135, що свідчить про абсолютну комунікативну інтолерантність до школярів і повне заперечення дотримання норм справедливості у педагогічній взаємодії. Максимальний вияв учителем указаної особливості значною мірою позначається на негативному психоемоційному стані школярів, на порушенні ïx психічного, духовного та емоційного здоров'я (De Cremer \& Ruiter, 2003; Lei Shi, 2015). Зменшення кількості набраних балів означає зниження рівня інтолерантності та підвищення рівня толерантності. Чим нижчим у досліджуваних виявлявся показник інтолерантності, тим більшою мірою це вказувало на властиве їм толерантне ставлення до учнів у комунікативній взаємодії.

Крім цієї методики, в процесі дослідження ми застосовували метод бесіди. Він дозволив отримати інформацію про вияви комунікативної толерантності окремих досліджуваних, зробити узагальнення про значення цієї якості у досягненні вчителями справедливості у взаємодії зі школярами.

Дослідження проводилося на базі Кіровоградського обласного інституту післядипломної педагогічної освіти імені В.О. Сухомлинського та серед магістрантів випускного курсу Центральноукраїнського державного педагогічного університету імені Володимира Винниченка, які суміщали навчання в університеті та педагогічну діяльність у школі. Вибірку досліджуваних становили вчителі з незначним педагогічним стажем - від 0 до 5 років (1 група) та вчителі, які працюють у закладах загальної середньої освіти від 6 до 20 років (2 група), мають певний досвід вирішення складних педагогічних ситуацій i комунікативної діалогічної взаємодії з учнями.

\section{Результати та дискусії}

Застосування методики «Діагностика комунікативної толерантності» (авт. В.В. Бойко) дало можливість зафіксувати результати, які відображені в таблиці 1.

Як видно з таблиці 1, комунікативна толерантність досліджуваних у різноманітних ситуаціях педагогічної взаємодії має різний ступінь вияву. Так, у вчителів з педагогічним стажем 0-5 років переважає середній рівень розвитку здатності приймати індивідуальність учнів (63,3\%), порівняно зі старшими колегами з досвідом роботи в школі 6-20 р. (36,7\%). Тоді як у останніх домінує високий рівень цієї особливості $(59,4 \%)$, у порівнянні з молодшими колегами $(38,1 \%)$. Схожа картина спостерігається і відносно такої особливості вчителів як 
тенденція не оцінювати учнів на основі власного «Я»: у вчителів 3 досвідом 0-5 р. переважає середній рівень (41,5\%), а у вчителів 3 досвідом 6-20 р. - високий (60,0\%). Разом з тим, виявлено, що в останніх низький рівень указаної особливості (12,5\%) теж домінує, порівно з учителями зі стажем 0-5 p. (8,2\%). Це ми пояснюємо тим, що 3 досвідом і набутою впевненістю в правильності власних педагогічних дій, учителі зі стажем від 6 до 20 років виявляють певну орієнтованість на власне професійне «Я», довіряючи суб'єктивним враженням відносно ситуації взаємодії з учнями.

Таблиия 1

Кількісні показники розвитку комунікативної толерантності у вчителів

\begin{tabular}{|c|c|c|c|c|c|c|}
\hline \multirow{2}{*}{$\begin{array}{c}\text { Комунікативна толерантність у } \\
\text { різних ситуаціях педагогічної } \\
\text { взаємодії }\end{array}$} & \multicolumn{2}{|c|}{$\begin{array}{c}\text { Низький } \\
\text { рівень }\end{array}$} & \multicolumn{2}{|c|}{$\begin{array}{c}\text { Середній } \\
\text { рівень }\end{array}$} & \multicolumn{2}{|c|}{$\begin{array}{c}\text { Високий } \\
\text { рівень }\end{array}$} \\
\hline & $\begin{array}{l}1 \text { група } \\
\mathrm{n}=147 \\
(\mathrm{y} \%)\end{array}$ & $\begin{array}{l}2 \text { група } \\
\mathrm{n}=160 \\
(\mathrm{y} \%)\end{array}$ & $\begin{array}{l}1 \text { група } \\
\mathrm{n}=147 \\
(\mathrm{y} \%)\end{array}$ & $\begin{array}{l}2 \text { група } \\
\mathrm{n}=160 \\
(\mathrm{y} \%)\end{array}$ & $\begin{array}{l}1 \text { група } \\
\mathrm{n}=147 \\
(\mathrm{y} \%)\end{array}$ & $\begin{array}{l}2 \quad \text { група } \\
n=160 \\
(\mathrm{y} \%)\end{array}$ \\
\hline $\begin{array}{l}\text { Здатність приймати } \\
\text { індивідуальність учнів }\end{array}$ & 0 & 2,5 & 63,3 & 38,1 & 36,7 & 59,4 \\
\hline $\begin{array}{l}\text { Тенденція не оцінювати учнів } \\
\text { на основні власного Я }\end{array}$ & 8,2 & 12,5 & 41,5 & 27,5 & 50,3 & 60,0 \\
\hline $\begin{array}{l}\text { Відсутність категоричності в } \\
\text { оцінці учнів }\end{array}$ & 3,4 & 3,8 & 53,7 & 50,0 & 42,9 & 46,2 \\
\hline $\begin{array}{l}\text { Приховування негативного } \\
\text { ставлення до учнів }\end{array}$ & 4,8 & 21,9 & 59,2 & 25,0 & 36,0 & 53,1 \\
\hline $\begin{array}{l}\text { Схильність не переробляти } \\
\text { учнів }\end{array}$ & 12,2 & 12,5 & 13,6 & 30,6 & 74,2 & 56,9 \\
\hline $\begin{array}{l}\text { Схильність не пристосовувати } \\
\text { до себе учнів як партнерів по } \\
\text { спілкуванню }\end{array}$ & 7,5 & 4,4 & 51,7 & 28,8 & 40,8 & 66,8 \\
\hline $\begin{array}{l}\text { Не властиві негативні } \\
\text { поведінкові тенденції }\end{array}$ & 12,2 & 9,4 & 24,5 & 38,1 & 63,3 & 52,5 \\
\hline $\begin{array}{l}\text { Терпимість до дискомфортних } \\
\text { негативних станів учнів }\end{array}$ & 12,2 & 6,2 & 21,3 & 23,2 & 66,5 & 70,6 \\
\hline $\begin{array}{l}\text { Адаптивність у взаєминах } 3 \\
\text { учнями }\end{array}$ & 2,7 & 6,2 & 12,2 & 22,5 & 85,1 & 71,3 \\
\hline
\end{tabular}

Щодо такої особливості як приховування негативного ставлення до учнів, то середній рівень домінує у вчителів-початківців (59,2\%), на відміну від учителів з досвідом 6-20 років, у яких переважають високий $(53,1 \%)$ і низький $(21,9 \%)$ рівні. Як бачимо, досвідчені вчителі не $\epsilon$ одностайними у питанні приховування негативних емоцій відносно учнів, що пояснюється їх самодостатністю: вони виходять із власної мотивації - чи оприлюднювати своє ставлення, чи, навпаки, його завуальовувати, що не завжди позитивно позначається на характері взаємодій з учнями. Останні мають розуміти якість ставлення до себе, усвідомлювати його причини для того, щоб діяти правильно й у відповідь отримувати справедливий вердикт.

Схильність не пристосовувати до себе учнів як партнерів по спілкуванню переважно виявляють старші за віком і стажем учителі (66,8\%), тоді як у педагогів-початківців ця 
особливість більшою мірою властива учителям зі стажем до 5 років. Варто відзначити низькі показники за цією особливістю у обох вибірок, що означає наявність поваги до учнів, їх особистості. Вказане підтверджується домінуванням високого рівня розвитку у обох вибірок особливостей не переробляти учнів, приймати їх такими, якими вони $\epsilon$ (74,2\% учителівпочатківців і 56,9\% досвідчених учителів) та не виявляти негативні поведінкові тенденції (63,3\% вчителів зі стажем до 5 років та 52,5\% вчителів зі стажем 6-20 р.). Це пов'язано 3 тим, що досліджувані мають високі показники адаптивності у взаєминах з учнями (85,1\% учителівпочатківців і 71,3\% досвідчених учителів).

Щодо відсутності категоричності в оцінияі учнів, то в обох вибірках досліджуваних переважає середній рівень (53,7\% у вчителів 3 досвідом 0-5 p. і 50,0\% 3 досвідом 6-20 р.). Варто відзначити також, що синхронні показники мають обидві вибірки у вияві особливості терпимості до дискомфортних негативних станів учнів - домінує високий рівень (66,5\% у вчителів-початківців і 70,6\% у досвідчених учителів).

Як засвідчують отримані результати, досліджувані обох вибірок мають мінімальні показники низького рівня толерантності, що виявляється у різних ситуаціях педагогічної взаємодії. Позитивно, що домінують середній і високий рівні. Загалом вищі показники мають учителі зі стажем 6-20 р. Втім саме представники цієї групи, маючи значний досвід комунікативної взаємодії з учнями та вирішення складних педагогічних ситуацій, виявляють більшу впевненість у справедливості власних дій, а тому часом схильні до категоричності щодо окремих школярів.

У процесі проведення методики «Діагностика комунікативної толерантності» (авт. В.В. Бойко) було також виявлено рівень розвитку загальної комунікативної толерантності. Отримані результати проілюстровано на рис. 1.

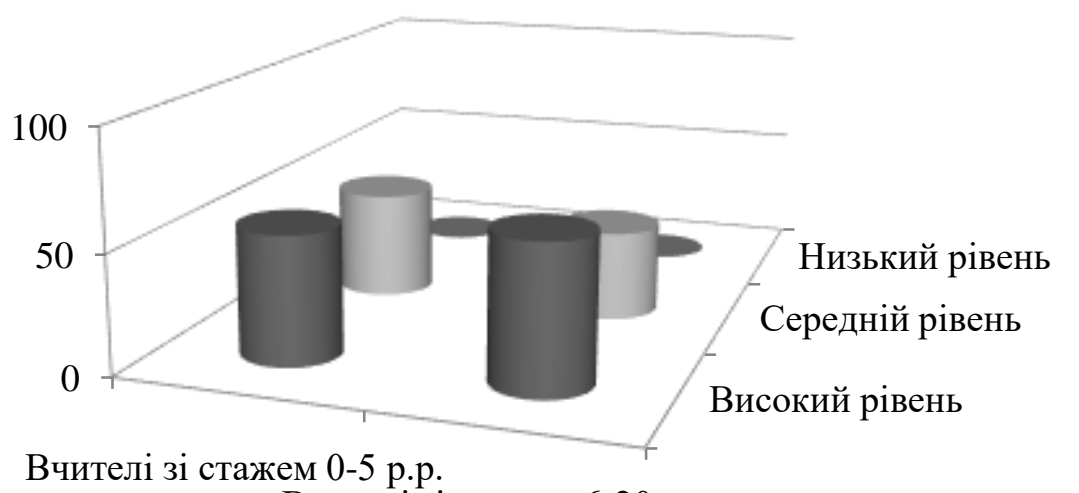

Вчителі зі стажем 6-20 p.p.
Високий рівень

Середній рівень

- Низький рівень

Рис. 1. Кількісні показники розвитку загальної комунікативної толерантності вчителів

На рис. 1 видно, що і в досліджуваних з тривалістю педагогічного стажу 0-5 р., і в тих, то працює в школі 6-20 р., результати розподіляються між високим і середнім рівнями. Вчителі, для яких властивий високий рівень комунікативної толерантності $(54,4 \%$ зі стажем 0-5 p. і 61,9\% зі стажем 6-20 р.) більшою мірою виявляють схильність позитивно сприймати обставини шкільної реальності. Вони легко встановлюють контакт з учнями, з розумінням ставляться до їх проблем та запитів, поважають особистість кожного. Ці вчителі так 
висловлюють критичні зауваження щодо неправильних виявів учнів, що в останніх виникає почуття відповідальності за власні дії, а не обгрунтованої образи. Учні усвідомлюють справедливе ставлення до себе вчителя, а тому отримане на свою адресу педагогічне рішення розцінюють як неупереджене: педагогічне покарання мислиться як заслужене, а визнання сприймається як винагорода за результати власних зусиль. Вказане мінімізує ймовірність виникнення конфліктів у педагогічній взаємодії.

Під час бесід з учителями, яким властивий високий рівень загальної комунікативної толерантності, ми фіксували відсутність у них негативного ставлення до учнів та звички критикувати їх публічно. Натомість учителі вказували на те, що віддають перевагу індивідуальним бесідам, зважають на пояснення школярів щодо мотивації власної поведінки, намагаються власними переконаннями чи рішеннями корегувати вияви учнів. Позитивним моментом $є$ те, що останні дослухаються до настанов, не ігнорують їх та відповідально ставляться до своїх учнівських обов'язків.

Середній рівень загальної комунікативної толерантності було виявлено у 45,8\% учителів з педагогічним стажем 0-5 років, та у 38,1\% зі стажем 6-20 р. Ці вчителі в цілому позитивно ставляться до учнів, схильні вислуховувати їх думки. У процесі педагогічного діалогу виявляють поважливе ставлення до кожного школяра. Втім спостерігається особливість учителя при зовнішній демонстрації прийняття особистості учня оцінювати його на основі власного «Я», що психологічно дистанціює учасників взаємодії та стоїть на заваді досягнення оптимального результату. У процесі проведення бесід ми виявили, що по відношенню до вчителів із середнім рівнем розвитку комунікативної толерантності учні виявляють незначну стриманість. Вони хоча й не заперечують неупередженість свого вчителя, але й не виявляють захоплення ним як справедливим, авторитетним педагогом, до якого $\epsilon$ почуття глибокої поваги та вдячності.

Позитивно, що в обох вибірках досліджуваних не виявлено низького рівня комунікативної толерантності. Це означає, що і вчителі з незначним педагогічним стажем, i вчителі з набутим досвідом комунікативної взаємодії з учнями схильні будувати $з$ ними стосунки, не нівелюючи особистість кожного, через діалог доносити настанови, слідування яким позитивно позначається на особистісному та моральному розвитку зростаючої особистості. Вияв учителями комунікативної толерантності у взаємодії з учнями зумовлює винесення неупереджених педагогічних рішень, за якими слідують відповідні дії. Усвідомлення учнями справедливості вчителя мінімізує ймовірність виникнення непорозумінь і конфліктів у педагогічній взаємодії, позитивно позначається на емоційному благополуччі учнів та сприяє психічному здоров'ю обох учасників освітнього процесу (Garbarino, 2018).

\section{Висновки}

Вивчення особливостей комунікативної толерантності вчителів як чинника справедливості у педагогічній взаємодії дозволяє сформулювати наступні висновки.

1. Толерантність є особистісним утворенням учителя, що виявляється в повазі до особистості учня та його поглядів, у розумінні причин поведінкових виявів.

2. Досягнення справедливості у взаєминах учнів і вчителя зумовлюється виявом останнім комунікативної толерантності. Вона виступає якістю (цінністю) педагога, що у діалогічній взаємодії зі школярами виявляється у прийнятті особистості кожного 3 них, розумінні мотивації поведінки, повазі до ціннісно-смислових позицій та установок. 
3. Рівень розвитку комунікативної толерантності вчителя свідчить про ступінь ціннісного ставлення до учнів, готовність будувати стосунки з ними на засадах гуманності та справедливості.

4. За результатами емпіричного дослідження, загальна комунікативна толерантність досить розвинена в сучасних учителів. I в учителів-початківців, і у педагогів, які мають набутий професійний досвід, переважають середній і високий рівні загальної комунікативної толерантності. Разом з тим, констатовано, що в різноманітних ситуаціях вказана особливість має різний ступінь вияву. У вчителів з незначним педагогічним стажем переважає середній рівень здатності приймати індивідуальність учнів, оцінювати їх на основні власного «Я», приховування негативного ставлення до них. У вчителів, які мають чималий педагогічний досвід, більшою мірою розвинена схильність приймати учнів з їх перевагами та недоліками, не вдаватися до негативних поведінкових тенденцій та виявляти адаптивність у взаєминах. Указані особливості вчителів та відсутність категоричності в оцінці учнів зумовлюють досягнення справедливості у педагогічній взаємодії.

Перспективи подальших досліджень ми вбачаємо у вивченні ситуацій інтолерантного ставлення вчителів до учнів у процесі комунікативної взаємодії, причин цього явища, його вплив на розвиток особистості та поведінкові вияви зростаючої особистості, якість взаємин учасників освітнього процесу.

\section{Література}

1. Бродский, Д. (2002). Некоторые психологические основы социальной толерантности. Права ребёнка и толерантность. Использование сообщества в рамках обучающего прочесса, (с. 142-159). Ростов-на-Дону : Дана,.

2. Карпюк, Ю.Я. (2019). Комунікативна толерантність як детермінанта професійної компетентності сучасного психолога. Теорія і практика сучасної психологї̈, 5(1), 93-99.

3. Клочек, Л.В. (2019). Психологія соціальної справедливості у педагогічній взаємодії (Дис. д-ра психол. наук). Київ.

4. Кремень, В.Г. (2011). Толерантність як імператив: національна ідентичність в добу глобалізації. Політичний менеджмент, 2, 14-32.

5. Кузьменко, P.І. (2020). Толерантність в людському бутті: екзистенціальні та гендерні виміри (Дис. доктора філософії). Київ.

6. Липатов, В.А. (2008). Семантические подходы к определению социальной толерантности. Материаль международного Форума студенческих научных обществ и молодых ученых духовных и светских учебных заведений, (с. 46-54). Курск : Славянка. Режим доступа:

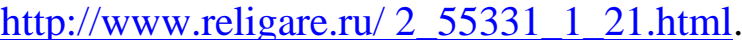

7. Скок, А.Г. (2011). Модель навчання толерантності. Вісник Чернігівського національного педагогічного університету імені Т.Г. Шевченка: Психологічні науки, 94(II), 162-164.

8. Фетискин, Н.П. (2002). Сочиально-психологическая диагностика развития личности $u$ мальхх групn. Москва : Ин-т Психотерапии.

9. Хамитов, Н.В (2009). Этика и эстетика. Словарь ключевых терминов. Киев : КНТ.

10. De Cremer, D., \& Ruiter, R.A.G. (2003). Emotional reactions toward procedural fairness as a function of negative information. The Jornal of Social Psychology, 143, 793-795.

11. Garbarino, J. (2018). The impact of anticipated reward upon cross-age tutoring. Journal of Personality and Social Psychology. 32(3), 421-428. Retrieved from https://psycnet.apa.org/doi/10.1037/h0077087.

12. Lei, Shi (2015). The study of the influence of the work stress on job burnout of knowledge-based employee - Based on the regulating effect of emotional intelligence. Proceedings of the 2015 International Conference on Industrial Technology and Management Science, 1627-1630. Retrieved from https://doi.org/10.2991/itms-15.2015.396. 
13. Tourinan, Lopez, \& Familia, J.M. (2008). Escuela y sociedal civil. Agentes de educacion intercultural. La Coruna : Netbiblo.

\section{References}

1. Brodskyi, D. (2002). Nekotorie psykholohycheskye osnovi sotsyalnoi tolerantnosty [Some psychological foundations of social tolerance]. Prava rebenka y tolerantnost. Yspolzovanye soobshchestva $v$ ramkakh obuchaiushcheho protsessa, (pp. 142-159). Rostov-na-Donu : Dana, [in Russian].

2. Karpiuk, Yu.Ia. (2019). Komunikatyvna tolerantnist yak determinanta profesiinoi kompetentnosti suchasnoho psykholoha [Communicative tolerance as a determinant of professional competence of a modern psychologist]. Teoriia i praktyka suchasnoi psykholohii, 5(1), 93-99 [in Ukrainian].

3. Klochek, L.V. (2019). Psykholohiia sotsialnoi spravedlyvosti u pedahohichnii vzaiemodii.[Psykholohiia sotsialnoi spravedlyvosti u pedahohichnii vzaiemodii]. Doctor's thesis. Kyiv [in Ukrainian].

4. Kremen, V.H. (2011). Tolerantnist yak imperatyv: natsionalna identychnist v dobu hlobalizatsii [Tolerance as an imperative: national identity in the age of globalization]. Politychnyi menedzhment, 2, 14-32 [in Ukrainian].

5. Kuzmenko, R.I. (2020). Tolerantnist v liudskomu butti: ekzystentsialni ta henderni vymiry [Tolerance in human existence: existential and gender dimensions]. Doctor's thesis. Kyiv [in Ukrainian].

6. Lypatov, V.A. (2008). Semantycheskye podkhodi k opredelenyiu sotsyalnoi tolerantnosty [Semantic approaches to the definition of social tolerance]. Materyals mezhdunarodnoho Foruma studencheskykh nauchnskh obshchestv y molodskh uchenskh dukhovnskh y svetskykh uchebnskh zavedenyi, (pp. 46-54). Kursk : Slavianka. Retrieved from http://www.religare.ru/ 2_55331_1_21.html [in Russian].

7. Skok, A.H. (2011). Model navchannia tolerantnosti [Tolerance learning model] Visnyk Chernihivskoho natsionalnoho pedahohichnoho universytetu imeni T.H. Shevchenka: Psykholohichni nauky, 94(II), 162-164 [in Ukrainian].

8. Fetyskyn, N.P. (2002). Sotsyalno-psykholohycheskaia dyahnostyka razvytyia lychnosty y malikh hrupp.[Socio-psychological diagnosis of personality development and small groups]. Moscow : Yn-t Psykhoterapyy [in Russian].

9. Khamytov, N.V. (2009). Etyka y Estetyka. Slovar kliuchevikh termynov. [Ethics and aesthetics. Dictionary of key terms]. Kyiv : KNT[in Ukrainian].

10. De Cremer, D., \& Ruiter, R.A.G. (2003). Emotional reactions toward procedural fairness as a function of negative information. The Jornal of Social Psychology, 143, 793-795.

11. Garbarino, J. (2018). The impact of anticipated reward upon cross-age tutoring. Journal of Personality and Social Psychology. 32(3), 421-428. Retrieved from https://psycnet.apa.org/doi/10.1037/h0077087.

12. Lei, Shi (2015). The study of the influence of the work stress on job burnout of knowledge-based employee - Based on the regulating effect of emotional intelligence. Proceedings of the 2015 International Conference on Industrial Technology and Management Science, 1627-1630. Retrieved from https://doi.org/10.2991/itms-15.2015.396.

13. Tourinan, Lopez, \& Familia, J.M. (2008). Escuela y sociedal civil. Agentes de educacion intercultural. La Coruna : Netbiblo. 


\title{
COMMUNICATIVE TOLERANCE AS A PSYCHOLOGICAL FACTOR OF JUSTICE IN PEDAGOGICAL INTERACTION \\ Liliia Klochek \\ Doctor of Psychological Sciences, Associate Professor, Associate Professor of the Department of Philosophy, Political Science and Psychology \\ Volodymyr Vynnychenko Central Pedagogical University \\ 1, Shevchenko Str., Kropyvnytskyi, Ukraine, 25000 \\ Klochek155@i.ua, http://orcid.org/0000-0002-6450-3374
}

\author{
Igor Ulychniy \\ PhD in Psychology, Associate Professor of the Department \\ Pedagogy of Special and Social Education \\ Volodymyr Vynnychenko Central Pedagogical University \\ 1, Shevchenko Str., Kropyvnytskyi, Ukraine, 25000 \\ ulychil@gmail.com
}

\begin{abstract}
The article presents the results of theoretical and empirical study of communicative tolerance. Tolerance is defined as the teacher's personal formation, which is manifested in their respect for the personality of the student, student rights and is associated with the assertion of the dual dominance of the participants positions in pedagogical interaction. It is specified that the achievement of justice in the relationship between students and teachers is conditioned by the manifestation of the latter's communicative tolerance. It acts as a quality (value) of the teacher who in communicative dialogic interaction with school students is manifested in the acceptance of the personality of each of them, understanding their behavior motivation, respect for value-notional positions and attitudes. It is noted that the level of development of communicative tolerance of the teacher indicates the degree of value attitude towards students, his/her willingness to build relationships on the principles of humanism and justice. The article provides the results of empirical research, according to which general communicative tolerance is sufficiently developed in a modern native teacher. It is established that both beginner teachers and teachers having acquired professional experience possess medium and high levels of general communicative tolerance. However, it is stated that in different situations, this feature has a different degree of manifestation. Teachers having little teaching experience, compared to senior colleagues, possess the medium degree of ability to accept the individuality of students, assess them on the basis of their own sense of self, hide the negative attitude towards them. It was found that to a greater extent the teachers having sufficient pedagogical experience demonstrate the tendency to accept students with their advantages and disadvantages, not to resort to negative behavioral tendencies and to show adaptability in relationships. It is generalized that the specified features of the teacher and lack of categoricalness while estimating the students are the conditions for achievement of justice in pedagogical interaction.
\end{abstract}

Keywords: justice, communicative tolerance, just actions, objectivity, impartiality.

Подано 13.09.2021

Рекомендовано до друку 23.09.2021 